\title{
The Image of Women in Selected Novels by Theodore Dreiser:
}

Darwinist and Feminist Approaches

\section{Submitted by \\ Mohamed Hassan Hosni Mahmoud Sotohy}

\begin{abstract}
The purpose of this research is to explore the image of women in selected novels by Theodore Dreiser and his Darwinist/feminist views. This research discusses the distinguished and the unpreceded view of Theodore Dreiser in portrayal of his female characters in a dual frame (a Darwinist/Feminist view).

The aim of the study is to show that Dreiser manages to combine between Darwinist and Feminist views in his novels and how his depiction of women was.

This research focuses on Theodore Dreiser's concept and treatment of women in his novels "Sister Carrie" and "An American Tragedy", which is different from other writers' opinions, and

illustrates Theodore Dreiser's treatment of women inside the circle of rebellion against environment and the conflict between his characters' desires and the surrounding society or environment.
\end{abstract}




\section{Introduction}

Theodore Dreiser, (1871-1945) is a fam screenwriter, who was a practitioner of naturalis rican writer, novelist and san notice that his novels

discuss the new social problems and issues that emerged in the rapidly-improving industrial America at the end of the $19^{\text {th }}$ century and the beginning of the $20^{\text {th }}$ century such as the degeneration of morality and the feverish struggle for wealth and possessing money that overwhelmed all human beings. All these ills and others resulted from the new industrialism that was marked by rapid boost. Dreiser handled these problems and tried to show that human beings are controlled by external powerful forces and those men and women are merely products of their environment.

In Theodore Dreiser (1946), James Farrell gives us a historical background about Dreiser; Farrell maintains that Dreiser has written long autobiographical works, which are unique for their self-honesty.

Talking about Dreiser and his style of writing, one should maintain that in Theodore Dreiser by James Lundquist (1977), Robert E. Spiller explains that Theodore Dreiser is one of the most puzzling authors in American literary history. Uneducated, clumsy in both person and literary style, convinced that man is help- less in a mechanistic universe, he nevertheless stands at the beginnings of modern era as the novelist who founded the naturalistic movement in American fiction and so made possible a more dynamic and honest novel than any of his predecessors had achieved.(Spiller, 166)

However, there is no controversy or dispute about Dreiser's greatness in the literary field. In Dreiser's Views on Art and Fiction (1979), R. N. Mookerjee maintains that Theodore Dreiser has undoubtedly been one of the important shaping and liberating forces in twentieth-century American literature. Sinclair Lewis, very appropriately, described the feelings of the literary world when in his Nobel Prize acceptance speech, Mookerjee said: "Now to me, as to many other American writers, Dreiser, more than any other man, is marching alone. Usually unappreciated, often hounded, 
he has cleared the trail from Victorian Howellsian timidity and gentility in American fiction to honesty, boldness, and passion of life. Without his pioneering I doubt if any of us could, unless we liked to be sent to jail, seek to express life, beauty and terror." (Mookerjee, 338)

Dreiser was gifted examining eyes that observe the goods and the evils of the society, and sensitive precise fingers to translate what he sees into details.

Dreiser's style was also influenced by Darwinism as Dreiser himself was affected by Darwin's theory of evolution, "Darwinism" though not in biology like Darwin. Dreiser means a "Darwinism" that pertains to human race, an adaptation with surrounding environment, and also Darwin's view of women. Those were the aspects, on which Herbert Spencer had built his "Social Darwinism".

Dreiser reflected the true nature of society and environment and conveyed the struggle which exists between them. He also embraced the speculations of Herbert Spencer. Through his readings and his own experience, Dreiser believed that human beings are disabled in the hold of impulses and social powers over their control, and he considered human society as an unfair competition between the strong and the weak.

One of the most important points that convinces one in Dreiser's style is that he is so honest and candid; he portrayed his protagonists and his characters up to an epitome of his philosophy and experience in life. He was an honest writer to the core to the extent that the main character in his first novel "Sister Carrie" (1900) represents one of his sisters. 
Dreiser managed to deal with the two approaches together in his novels and in portraying his characters. In the three chosen novels in this thesis, Dreiser handles the two contradictory aspects of the Darwinist and the Feminist approaches. This is what this study aims to focus on, the Darwinist/Feminist image of woman according to Dreiser's concept.

Another point about Dreiser's style in handling his $\quad 2 \quad \mathrm{~s}$ is that he approaches embarrassing and weird aspects of characters, suclı aspous that were taboo at his time. As a result, he had them have a battle with censorship. However, he refused not to deal with all aspects of personality including untackled or taboo aspects. This is his candidness. Sister Carrie is considered a milestone in Dreiser's literary career.

\section{1- Research objectives:}

This thesis discusses the image of woman in Dreiser's novels from a dual perspective (Darwinist and feminist) through discussing some novels of Dreiser.

\section{The methods of the research}

This thesis uses three main approaches, namely Natıralism. Darwinism and social Darwinism and Feminism which are closely $3 \mathrm{~d}$ with the author's preoccupations and insights in dealing with the characters in his novels.

Naturalism: In The Penguin Dictionary Of Literary Term (1992), J.A.Cuddon defines naturalism as: 
Naturalism in literary criticism, a word sometimes used loosely as a synonym for realism, and also in reference to works which show a pronounced interest in, sympathy with and love of natural beauty (e.g. much of the poetry of Wordsworth). Properly speaking, it should be used to describe works of literature which use realistic methods and subjects to convey a philosophical form of naturalism; that is, they believe that everything that is found is a part of nature and can be interpreted by natural and material causes - and not by supernatural, spiritual or paranormal causes. (Cuddon, 573).

Charles Darwin's theory of evolution has a direct influence on American naturalistic writers. Darwin's influence on these authors, particularly Dreiser, has been explored for the most part only in terms of Herbert Spencer's "social Darwinist" ideas; Dreiser's evolutionary thinking, however, is more complex than traditional explanations of the influence of "Spencer's social Darwinism." In an online article: "Naturalism in American Literature" Donna Campbell maintains that the main features of naturalism are:

1. Heredity and environment are the forces that shape human beings.

2. All Human beings are not free, they don't have free will, because hereditary elements and environment : $4 \quad$ werful in determining the course of human action.

3. A literary work should represent life actually as it is, without 
dressing or flattering.

The literary movement of naturalism is related to Darwin's theory of evolution which was modified and connected to sociology by the English Herbert Spencer who coined the principle of "the survival of the fittest" and wrote about social Darwinism which was applied to the most naturalistic writers and Dreiser is no exception, whereas he treated women and also his characters from the view of the conflict between man's desires and dreams and environment or heredity. (Campbell, Online Article)

Dreiser's novels discuss the new social problems and issues that emerged in the rapidly-improving industrial America at the end of the $19^{\text {th }}$ century and the beginning of the $20^{\text {th }}$ century such as the degeneration of morality and the feverish struggle for wealth and possessing money that overwhelmed all human beings. $\mathrm{He}$ tried to show that human beings are controlled by external powerful forces and those men and women are merely products of their environment.

In Theodore Dreiser (1946), James Farrell gives us a historical background about Dreiser; Farrell maintains that Dreiser has written long autobiographical works, which are unique for their self-honesty. Dreiser's father was an immigrant German worker; his mother was the daughter of Moravian parents who belonged to a small religious group in a farming region near Dayton, Ohio. Dreiser has described his father as a rigid, fanatically religious man; also he was honest, hard-working and slow. It is likely that he might have been an American success story on a small scale if he had had will and if he hadn't been so persist $\quad 5$ rested in trying to avoid 
the fires of technological Hell. Farrell notices that in Dreiser's writing, then, the father emerges as a strangely appealing and rather pathetic figure. Dreiser was deeply devoted to his mother all his life. His description of her in Dawn (1998), for instance, reveals her as an extremely emotional woman, one who gave to her large family all of the motherhood affection, warmth and security that she could. The role she played in Dreiser's life cannot be over-stepped: it is even well probable that except for her, his fate might have been akin to that of one of his own characters. He was, as a boy, shy, eager, timid, brooding, bewildered, slow to develop: he, himself, in very tender words, has written how all important her love and security was to him, as well as to his brothers and sisters. The element of personal experience and familiar background is more thoroughly woven into the patterns of Dreiser's novels than many critics have often thought. For instance, one of the main motifs of his fiction concerns the conflict between instinct and tradition. The biological needs of his characters lead them to take actions, particularly to love affairs, which result in agreements on the social code of the times. His autobiographical writings convey to us that he experienced this conflict most moving in his own early life, and that it was felt day in and day out in the family home as the children grew up. "The element of personal experience and intimate background is more thoroughly woven into the patterns of Dreiser's novels than many critics have often suspected. For instance, one of the central motifs of his fiction concerns the conflict between instinct and convention.” (Farrell, 128).

Dreiser's style was also influenced by Darwinism as Dreiser himself was affected by Darwin's theory of evolution "Darwinism" though not in biology like Darwin. Dreiser means a "Darwinism" that pertains to human race, an adaptation with 
surrounding environment, and also Darwin's view of women. Those were the aspects, on which Herbert Spencer had built his "Social Darwinism" principle. Dreiser reflected the true nature of society and environment and conveyed the struggle which exists between them. He also embraced the speculations of Herbert Spencer. Through his readings and his own experience, Dreiser believed that human beings are disabled in the hold of impulses and social powers over their control, and he considered human society as an unfair competition between the strong and the weak. Meanwhile, around Dreiser's time in Europe and America, naturalistic writers were influenced by Charles Darwin's theory of evolution. They believed that one's heredity and social environment determine one's character. Their works unveiled and criticized the ugly face of life, including poverty, racism, sexuality, violence, disease, corruption and prostitution. One of the most prevailing characteristics of naturalists is pessimism emphasizing the inevitability of death. Theodore Dreiser, as a representative of naturalism followed and applied the characteristics of naturalism in his works. He is known for imaging characters; their strength lies not in morals, but in their persistence, struggle and battling against all obstacles. One of the most important points that convince one in Dreiser's style is that he is so honest and great candid; he portrayed his protagonists and his characters up to an epitome of his philosophy and experience in life. He was an honest writer to the core to the extent that the main character in his first novel "Sister Carrie" (1900) represents one of his sisters. The novel is based partly on the immoral behavior of Dreiser's sister, Emma, who had a sexual relationship with a married man who stole money from the man whom he worked for. It tells a story about a young girl from the countryside who moves to the 
urban city of Chicago, and falls into a life of degradation in order to live and fulfill the "American dream".

In his novels Sister Carrie (1900) and An American Tragedy (1925), Dreiser attempts to handle the notion of social Darwinism. In this connection, his characters have a lust for money, fame and wealth. These overwhelming desires and lusts are to a great extent similar to those of animals, but the powerful and dominating heredity and environment stand roughly and strictly against the $\quad 7 \quad$ id manage to defeat them since environment and heredity determine one's fate. Inis study attempts to focus on the Darwinist image of woman according to Dreiser's concept. Dreiser is well known as a journalist, novelist and famous screen writer, and he is one of the most famous novelists who experienced life and swallowed up its hardness, bitterness and harshness, in every phase of his life. Since he was a child, his life deteriorated severely. He felt that he was in rapport with naturalism and he was reconciled to this school's principles and depiction of life. He has found that what he sees and observes matches what naturalism observes and spots, i.e., the lust and greed for wealth. In his works he depicted the relationship and the struggle between human and the surrounding environment honestly and frankly. Dreiser tried to convey the utilitarian approach of human beings, the love of existence, and the lust for fame, money and wealth, even the sexual desires, and he meant to show man's illusion in running after the fake sparkling desires in the modern industrial society and its lights which cause finally, determine his doom. 
This research discusses the image of woman in Dreiser's novels from dual perspective (Darwinist and feminist). However, is there any kind of relationship between Darwinism and feminism? For example, did Darwinism have a place in arguments about the ‘women question'? Secondly what was Darwin's thought about women's issue? In Darwinism, Feminism, and the Sonnet Sequence: Meredith's "Modern Love" (2010), John Holmes maintains some answers to the previous questions, Holmes maintains that the place of Darwinism in arguments over the "woman question" in the late nineteenth century was distinctly ambiguous. On the one hand, many chief evolutionists including Darwin himself took what they perceived to be the lesser cultural and intellectual achievement of women in Victorian society and across history as a biological fact, thereby naturalizing female inferiority.

Dreiser choses to write about women, his 8 d consideration of women characters were different from other writers; In Theodore Dreiser: Interviews (2004), Frederic E. Rusch reports the following:

Mr. Dreiser said, as he lapsed into thought for a moment...."1 think one reason I wrote chiefly about woman," he went on, "is that, as I look at it, she symbolizes the essentially artistic character of the universe more than man does. Everything in life is artistic in essence. But, of the two, man symbolizes power to me, while woman stands for beauty - which is art. She produces the same effect as music, poetry, or a Greek amphora. "Another reason is that woman is at present what I would call the time idea - the thing in which the age 
is preeminently interested. This has been the century of the woman. (Rusch, 15)

From the previous comment by Dreiser, One can understand Dreiser's idea or image of woman and the reason for his admiration of woman.

Darwinism: is a term that goes back to Charles Darwin. Darwin's theory of evolution and natural selection proves that only the fit and strong elements will be able to survive and remain. As a fact, Darwin's theory of evolution is inescapable for all naturalist writers. In her Ph.D dissertation "The Darwinian Presence in American Painting ", Carol J.Guttzeit writes that:
"Even with over one hundred years of hindsight, the truth of this statement remains. It is hard for any person living during the twentieth century to imagine a society, indeed an entire world, without Darwin" (Guttzeit, 1).

Since this research deals with the image of wom: 9 :iser's works from both Darwinist and feminist perspectives; therefore feminism as a literary term must be discussed in detail. An illustrative background will be given about the definition of the term, the history of the term, famous feminist writers, about Theodore Dreiser's relationship with Darwinism and if there is a relationship between Dreiser and feminism. In Feminism (2001), Susan Osborne tries to define feminism saying that when you try searching the Internet and you will come up with pages of definitions, many subtly different. 
Feminism, The Oxford Concise Dictionary of Politics gives this definition:

Feminism is a way of looking at the world, which women occupy from the perspective of women. It has as its central focus the concept of patriarchy, which can be described as a system of male authority, which oppresses women through its social, political and economic institutions. (Osborne, 8)

The Chambers Dictionary puts it more simply as the 'advocacy of women's rights, or of the movement for the advancement and emancipation of women'. Osborne then offers a short history about women's movement, she says that the origins of the women's movement in the Western world can be followed back to the French Revolution which began in 1789 .

Feminism or women's movement is one of the effective movements that affected the history of the world and it is an essential part of this thesis, to give a historical background about the feminist movement. Now comes an urgent question, how was Dreiser's view of woman? What was his perspective about her? In Running with Diana: Dreiser's Hunt of American Endogamy (2000), Roark Mulligan says:

Theodore Dreiser begins and ends his poem "Diana" with the refrain: "Are you truly friendly / Oh, Diana, / To the aspirations / And the souls / Of men?"1 This poetic a] 10 : to the chaste hunting goddess exemplifies Dreiser's ambivarent attitude towards women. For Dreiser, the goddess of the poem, the protectress of maidens, 
symbolized all women, and he paid tribute to these women by creating female characters who are realistic and complex. But he also feared his Dianas, knowing their neglect, could destroy men. (Mulligan, 140)

Diana is a Greek goddess of wild animals; she is the Greek goddess "Artemis". In Encyclopedia Britannica:

Diana, in Roman religion, goddess of wild animals and the hunt, identified with the Greek goddess Artemis. Her name is akin to the Latin words dium ("sky”) and dius (“daylight”). Like her Greek counterpart, she was also a goddess of domestic animals. As a fertility deity she was invoked by women to aid conception and delivery. (Encyclopedia Britannica, online)

Generally, the world had changed completely and severely almost in all fields during the $18^{\text {th }}$ century. Nobody can neglect the extremely huge effect of Darwin and his theory of evolution on the whole world and in all fields. Darwin's book On the Origin of Species (1859) was like dynamite in most scientific and even nonscientific fields. What matters here is what this book says about women. Since the present study is concerned with the image of women in selected novels by Theodore Dreiser from a Darwinist and feminist view, what matters here is what this book says about women. This will be seen in the following pages. 
Darwin's opinion of women isn't hostile, but he believes in the ability of the human race to live and evolve and adapt with the surrounding environment. In this respect, he thinks that women are weak and not strong enough to resist and live; they are not as clever as men. He considered women as inferior to men; they couldn't protect themselves, and nor protect the country or society. They are not strong and they don't have the constituents of life. Harun Yahya in his book The Social Weapon (2006) discusses Darwin's view of women as follows:

Darwin described women as an "inferior" species, because his universal view was dependent up on natural selection. When one thinks of Darwin's general views about women and marriage, one can see undoubtedly how he considered women as second-grade citizens. This unscientific opinion was also reflected in his theory of evolution. This is how he described why marriage was useful: ... children—constant companion, (friend in old age) who will feel interested in one, object to be beloved and played with—-better than a dog anyhow-Home, and someone to take care of houseCharms of music and female chit-chat. These things good for one's health (Yahya, 244).

As a literary school, Naturalism has been coined almost in 1867 during the life span of Darwin and his theory of evolution. In accordance with Darwinism, thoughts and principles of the literary school of naturalism work hand in gloves and find harmony with Darwin's theory of evolution. Theodore Dreiser was Zola's 
disciple and one of the most important leading, representative figures of the literary school of naturalism. As an immigrant, Dreiser himself lived his life struggling to have a place.

Dreiser followed the footprints of Zola and imitated him in his novel Jennie Gerhardt. There are some aspects of conformity between Zola's "Nana" and Dreiser's “Jennie Gerhardt”. Zola makes a divisi 12 en prostitute and mother, as well as the separation between classes. Dreiser also makes this division when he portrays the illegal relationship of Jennie with Senator Brander and her nature as a good and kind mother for Vesta. In Jennie Gerhardt Dreiser says:

The tremendous and complicated development of our material civilization, and in short, the whole machinery of social intercourse these elements of existence combine to produce what may be termed a kaleidoscopic glitter, a dazzling and confusing phantasmagoria of life that wearies and stultifies the mental and moral nature. It induces a sort of intellectual fatigue through which we see the ranks of the victims of insomnia, melancholia, and insanity constantly recruited. (Gerhardt, 80) 


\section{2- Dreiser's st}

Dreiser is a very distinguished writer in

; he portrays characters stormed by environmental forces that govern their fate. Moreover, his characters learn from life with its ups and downs, most of his characters don't learn at school or even from their ignorant religiously bigot parents. That kind of learning that Dreiser had chosen for his characters is the same of Dreiser's learning. Critics have drawn our attention to the importance of Theodore Dreiser as a novelist, and the features of naturalism, and to some feminist features in his novels, but no one has focused on the duality of portraying his heroines or his women-characters. He blended Darwinism and Feminism together while depicting his protagonists.

The society that surrounded Dreiser is explored so as to analyze his motives and his psyche while writing his novels. This will help us understand some concepts that this study has discussed, such as Darwinism, Social Darwinism, Naturalism and Feminism, and their effect on the American society. The American society had witnessed radical changes in all aspects of life because of its transition from the 
agriculture phase to the industrial phase. People left their farms to work in factories with machines. They moved from towns to cities seeking labor opportunities.

As a result, the society turns into a jungle in which each one works for satisfying his own instincts and desires, climbing on the shoulders of other people to reach his own goals. The writer has always held the mirror to the society in order to diagnose its evils and diseases in an attempt to reflect them and show people's suffering.

In order to pinpoint and illustrate the image of women in Dreiser's fiction, let's discuss his style and portray of women in one of his novels. In Jennie Gerhardt (1911) Dreiser introduces Jennie as a beautiful, sensitive e 14 ear-old girl, who is at the same time devoted to her family and shamed by he Jennie's father is unemployed and unable to support his family and this is the basic cause that forced Jennie to work in humiliating jobs; she was washing the floors of a local hotel. She was working in silence but out of her control she heard sounds, conversations and laughers of rich people around her. Her poor mother hoped all her life just they would have a larger house but in vain. As a poor and helpless girl, though beautiful at the same time, she became a victim to one of well-to-do "society predators", a prey for one of the "birds of prey" who hovered and restricted her till she surrendered and then he devoured her without mercy. Senator Brander was infatuated by Jennie; he set up his trap to get her by helping her family, releasing her brother out of jail, using his sweet words, and by his promise to marry her. The senator 
exploits this occasion to seduce the grateful Jennie He sleeps with her and leaves her pregnant. Unfortunately, he dies before he marries her.

She falls prey to one of the hotel's wealthy residents, Senator Brander. Attracted by Jennie's beauty and youth, the senator, thirtyfour years Jennie's senior, sympathizes with her family and gives money and gifts to the Gerhardts. Brander wins Jennie's affection with the promise of deliverance from poverty for both herself and her family. Jennie, fearful that her relationship with Brander suggests impropriety, resolves to reject the senator's beneficence, but in a critical moment she is forced to appeal to the senator for help in releasing her brother from jail. (Rains, 46)

If he is serious enough about the matter, and if he lnves her truly, he would marry her before he sleeps with her. But he proves us that he 15 of animals. And this is the dimension of the naturalistic school here, the animal desire inside the human being when it is motivated and controlled by the forces and the greater powers of the surrounding environment or conditions.

The consequences of this incident are tremendously hard upon Jennie; she is still poor. In addition, she has a baby. Her father, who was religiously a fanatic, dismissed her from the family home. Her father's attitude here is the society's attitude; cruel and tough.

In Jennie Gerhardt Dreiser moves on to the creation of some characters who are able to recognize his heroine's "emotional greatness" and whose relation to her provide her with the necessity to prove it. Senator Brander, for example, who is 
portrayed as a sensitive man, sees her deserves, he intends to marry her. His death and Jennie's delightful acceptance of her motherhood, in spite of the problems it must cause her, further prove the capacity of her nature to absorb its poetic aspirations in action. The fact that Lester, the most selfish of her relations, also sees her deserves before he dies, sets the final dramatic clue upon those qualities which Dreiser has posited for her. In viewing the naturalistic tradition, the problem of the expressive dimension of Dreiser's art causes the same critical dilemma which Henry James faced in his own efforts to estimate the art of Emile Zola. James notes that the novels of Zola have become more interesting to him as aspects of Zola's literary biography than as works of art. A key to the aesthetic appreciation of the novels in Dreiser's tradition involves an objection to the critical demand for the kind of strict control which so often ends up as a capacity for presenting character ironically (Burgan, 337-338).

Dreiser's opinion of Jennie is that she is a "natural" child of the earth, pure, free. For Dreiser Jennie represents the ideal woma $16 \quad$ 'er, middle-class society makes Jennie feel like a failure. Society, Dreiser suys, nunııs or creates an artificial environment for men and women. The true man or woman is a natural one, acting in accordance with his or her natural instincts and appetites. Society, on the other hand, unnaturally constrains. Jennie breaks the morals and the mores of society to help her family, so she feels conflict and learns that love only is not enough in this world (Rains, 70).

In a master's thesis in Bukhara State University under the title: "The Means of Describing Spirituality in the Works "Sister Carrie "and "Jennie Gerhardt" 
by Theodore Dreiser", Khayrullaeva Nadira writes about Dreiser's second novel Jennie Gerhardt. Nadira says that Jennie Gerhardt is an illustration of Dreiser's realization that material success leaves nothing but discontentment and dissatisfaction, the attitude of two contrasting characters Jennie is simple, unselfish and kindhearted. She doesn't care about money and material success. She sacrifices her life for the prosperity of others. Even though conventional society does not recognize her noble heart and mistreats her, she has no ill feeling towards people. She loves all, and is happy and contented. But, Lester, her lover, gives importance to wealth and luxury and finally expresses his dissatisfaction and unhappiness over the achievement of these aims.

Although Jennie was accused of being an immoral woman, Dreiser had a different view of her. Dreiser had a concept about virtue: He considers virtue as a kind of generosity which offers itself desirably for another's service and being this, it is held by society to be nearly worthless. In Jennie Gerhardt, Dreiser says:

Sell yourself cheaply and you shall be used lightly and trampled underfoot. Hold yourself dearly, however unworthily and you will be respected. Society in the mass lacks woefully in the matter of discrimination. It's one criterion is 17 on of others (Gerhardt, $60)$.

Dreiser did not criticize what Jennie had done; he felt great sympathy for her. Dreiser was with Jennie from the beginning, he sympathized with her and supported her all the way, he even didn't blame her for any misbehavior, and he justified her deeds and showed the good traits of her personality till the very end of the novel. He conveyed 
a good picture to the reader that Jennie is a self-sacrificing woman, kind hearted, very faithful, a good mother, a cooperative sister, a hard-working girl, an obedient daughter and loyal lover. For the part of her sexual relationships, first with Senator Brander, it was the price for releasing her brother Sebastian out of jail. The second relationship was with Lester Kane and she was forced into it to help her family after her father's accident which meant famine and abject poverty for all the family. In this way, Dreiser turned Jennie from a guilty and sinful girl to a pitiful and miserable one. If you want to blame, just blame the society, blame the predators instead of blaming the victims, and blame the birds of prey instead of blaming the helpless preys. As if Dreiser wants to show a cannibalistic world throughout the novel, a sea-like environment where sharks smash skulls and bones, cut veins and suck bloods of their victims without mercy.

Dreiser's novel Jennie Gerhardt deals with a feminist and, historically, its writing coincides with the formation of this moment. It shows woman's suffering, woman's role in the society. This novel was written in 1911 at a time which witnessed the rise of the First Wave of Feminism, which began in the late $19^{\text {th }}$ century and the early $20^{\text {th }}$ century. In the same period "Jennie Gerhardt" was published. Partaking of both views, which could be expressed in Shakespearean terms in Lear's plea that a man sinned more than sinning. Likewise, one couldn't help hearing Jennie Gerhardt's cry, "I am a woman more sinned against than sinning." Jennie is a victim of circumstances. She is not a prostitute or immoral character but she is a victim of environment and heredity, she couldn't find anothe 18 to survive or to help her family. She is obliged to sacrifice her own reputati........p her father, mother and 
her brother. She does this in remorse, birds of preys hover around her to satisfy their lust for their desires because she is a beautiful woman. She is not willing to deviate or behave immorally but Brander and later Lester compel her to deviate.

At the very beginning of the novel Dreiser tells us why she and her mother work at the hotel in Jennie Gerhardt Dreiser says: "Poverty was driving them" (Gerhardt, 1)

Dreiser narrates the miserable circumstances of Jennie's family in the following lines:

William Gerhardt, a glass-blower by trade. Having suffered the reverses so common in the lower walks of life, this man was forced to see his wife, his six children, and himself dependent for the necessaries of life upon whatever windfall of fortune the morning of each recurring day might bring. He himself was sick in bed. (Gerhardt, 2)

Jennie as a simple and innocent girl was taken by the luxury of Senator Brander, Dreiser tells us about this in chapter three:

As for Jennie, she was immensely taken with the comfort and luxury surrounding this man, and subconsciously with the man himself, the most attractive she had ever known. Everything he had was fine, everything he did was gentle, distinguished, and considerate. (Gerhardt, 17)

Brander exploited this opportunity as soon as she pleaded to him to save her brother out of jail and again after the death of Brander, Lester kane also exploited her 
innocence and beauty and made a relationship with Jennie by force but her inner consciousness is blaming her:

Jennie was now going through the agony of one who has a varied and complicated problem to confront. Her baby, her father, her brothers, and sisters all rose up to confront her. What was this thing that she was doing? Was she allowing herself to slip into another wretched, unsanctified relationship? How was she to explain to her family about this man? He would not marry her, that was sure, if he knew all about her. He would not marry her, anyhow, a man of his station and position. (Gerhardt, 83)

So Jennie is not willing to err but circumstances push her to. In another scene in the novel, Lester kisses her also by force, as the novel proceeds he marries her. If Jennie found another way to help her family, she wouldn't do anything wrong. At the end of the novel she stays with Lester until he dies and then she cries on him because she loves her husband and because she will miss him not because she will be poor again. Dreiser portrays Jennie as an ideal woman in a society without mercy, she was an old Jennie and now she becomes a new Jennie after all the experiences that she went through in the novel. She feels remorse and frustration, after losing Vesta first, and then she loses her beloved husband Kane. Jennie feels that she is lost in her upcoming new life.

\section{3- Conclusion}


Most critics have drawn our attention to the importance of Theodore Dreiser as a novelist, and the features of naturalism, and to some feminist features in his novels, but no one has focused on the duality of portraying his heroines or his womencharacters. He blended Darwinism and Feminism together while depicting his protagonists.

This study reconsiders Dreiser's philosophy and his dual style in dealing with his heroines and why he deals only with women in most of his novels, in general, and in the selected novels in this study in particular. This study is also an extended research about female actions in, and reactions to, surrounding environment; it is a description of human behavior at any time, as long as he is a human being having desires, instincts, and dreams to fulfill, and as long as there are powers and forces that always govern our destiny.

Secondly, this study focused on Theodore Dreiser as a representative of the Darwinist/Feminist image of women and the expression of this image. In fact, the choice of Dreiser is justified because of his wide experience, as a result of being immersed in the same type of environment and elements. In this connection, he didn't have any scruples in presenting the sensitive stories of his sisters' failures in his novels. In addition, he was contemporary to more than one movement in that period; he came after Spencer who followed Darwinism, he witnessed the literary school of naturalism, at that time the waves that called for the liberation of women.

The third frontier-point I have approached in this study is Dreiser's duality of depiction; through analyzing three of his novels; An American Tragedy in Chapter 2, Sister Carrie in Chapter.3, and Jennie Gerhardt in Chapter. 4. Each novel deals with the concepts of social Darwinism and Feminism. The duality of Dreiser was clear in Sister Carrie, when he described her innocence in the first chapter of the novel as he maintained that she was eighteen years old, bright, timid and full of illusions. In Jennie Gerhardt, for instance, he sympathizes with his heroine, Jennie Gerhardt, despite her moral fall, and emphasizes that she is a good daughter, mother and wife. 
This study also managed to explore the following:

This study has shown clearly that Dreiser in this \& 21 se of his career was a Feminist, and not as most people think, a social Darv $\quad y$, because he belonged to the literary school of naturalism.

In a wider human view point, this study's investigation of Dreiser's novels could be seen as empirical research about female actions and reactions towards surrounding environment; it is a description of human behavior at any time, as long as man is a human being, having desires, instincts, and dreams to fulfill, and as long as there are powers and forces governing his destiny. 


\section{References}

Burgan, Mary A. and Mary E. Burgan. "Sister Carrie" and the Pathos of Naturalism" Criticism,

Vol.15, no. 4, Wayne State University Press, Fall 1973, pp. 336-349. Jstor. http://www.jstor.org/stable/23099531

Cuddon, J.A. The Penguin Dictionary Of Literary Term. London: Penguin Books, 1992.

Campbell, Donna M. "Naturalism in American Literature. " Literary Movements.

Dept. of

English, Washington State University. 07April 2013. Web. 28Jan. 2018.

<http://public.wsu.edu/ campbelld/amlit/natural.htm>

"Diana Roman Religion". Encyclopadia Britannica. Encyclopaedia Britannica Online.

Encyclopædia Britannica Inc., 2017. Web. 9 Aug. 2017

https://www.britannica.com/topic/Diana-Roman-religion

Dreiser, Theodore. Jennie Gerhardt. US: Kissinger Publishing (1911,2010).

Dreiser, Theodore. Sister Carrie. NY: Barnes \& Nobles Classic (1900, 2005). 
Farrell, James T. "Theodore Dreiser Chicago Review”, Vol. 1, no. 3, Chicago Review, Summer 1946, PP. 127-144. Jstor, http://www.jstor.org/stable/25292739

Guttzeit, Carol Jean. The Darwinian presence in American painting, 1859-1900. 1996.

University of New Jersey. Ph.D Diss.

Mulligan, Roark. "Running with Diana: Dreiser's Hunt of American Endogamy" American

Literary Realism, Vol. 32, no. 2, : University of ?ress, Winter, 2000, pp. 140-151.

Jstor, http://www.jstor.org/stable/27746973.

Osborne, Susan. Feminism. UK: Pocket Essentials. 2001.

Rusch, E. Frederic. Theodore Dreiser: Interview. US: University of Illinois Press, 2004.

Spiller, Robert E. "Theodore Dreiser by James Lundquist" The Modern Language Review, Vol. 72, no. 1, Modern Humanities Research Association, Jan 1977, pp. 166. Jstor, http://www.jstor.org/stable/3726324.

Yahya, Harun. The Social Weapon. US: Global publishing, 2006. 